Article

\title{
Protein Hydrolysate from Pterygoplichthys disjunctivus, Armoured Catfish, with High Antioxidant Activity
}

\author{
Yuchen Guo ${ }^{1}$, Nicholas Michael ${ }^{2}$, Jorge Fonseca Madrigal ${ }^{3}$, Carlos Sosa Aguirre ${ }^{3}$ and \\ Paula Jauregi $1, *$ (D) \\ 1 Department of Food and Nutritional Sciences, University of Reading, Whiteknights, Harry Nursten Building, \\ Reading RG6 6AP, UK; gyc19901117@googlemail.com \\ 2 Centre for Analytical Facilities, Harborne Building, University of Reading, Reading RG6 6UR, UK; \\ n.michael@reading.ac.uk \\ 3 Universidad Michoacana de San Nicolas Hidalgo, Michoacan, Morelia 58030, Mexico; \\ jfonseca@umich.mx (J.F.M.); csosa@biofermich.com (C.S.A.) \\ * Correspondence: p.jauregi@reading.ac.uk
}

Received: 29 March 2019; Accepted: 19 April 2019; Published: 25 April 2019

\begin{abstract}
Pterygoplichthys disjunctivus, locally named the armoured catfish, is a by-catch of tilapia fishing that accounts for up to $80 \%$ of total captured fish in the Adolfo Lopez Mateos dam, in Michoacán, México, affecting the economy of its surrounding communities. This invasive fish is discarded by fishermen since native people do not consume it, partly due to its appearance, yet it is rich in protein. The aim of this study was to produce hydrolysates from armoured catfish using food-grade proteases (neutrases HT and PF and alcalase PAL) and investigate the processing conditions ( $\mathrm{pH}$ and temperature) that lead to a high degree of hydrolysis, antioxidant activity, and Angiotensin I-Converting Enzyme (ACE) Inhibitory activity. No other similar research has been reported on this underutilized fish. The antioxidant activity was measured by three different methods, ABTS, FRAP and ORAC, with relevance to food and biological systems in order to obtain a more comprehensive assessment of the activity. In addition, the main peptide sequences were identified. All enzymes produced hydrolysates with high antioxidant activity. In particular, the protease HT led to the highest antioxidant activity according to the ABTS (174.68 $\mu \mathrm{mol}$ Trolox equivalent/g fish) and FRAP (7.59 mg ascorbic acid equivalent/g fish) methods and almost the same as PAL according to the ORAC method ( $51.43 \mu \mathrm{mol}$ Trolox equivalent/g fish). Moreover, maximum activity was obtained at mild $\mathrm{pH}$ and temperature $\left(7.5 ; 50^{\circ} \mathrm{C}\right)$. Interestingly, the ORAC values obtained here were higher than others previously reported for fish hydrolysates and similar to those reported for fruits such as blueberries, apples and oranges. The peptide sequence IEE(E) was present in several peptides in both hydrolysates; this sequence may be partly responsible for the high antioxidant activity, particularly the one based on iron-reducing power. These findings will be relevant to the valorization of other fish/fish muscle discards and could contribute to the production of food supplements and nutraceuticals.
\end{abstract}

Keywords: armoured catfish; enzyme hydrolysate; ABTS; ORAC; FRAP; ACE inhibition; digestibility; peptide sequences

\section{Introduction}

The loricariid catfish (Pterygoplichthys disjunctivus), a species originally from South America [1], is a commercially valuable ornamental fish all over the world, commonly used to clean fish tanks of algae. However, the species has invaded different freshwater bodies throughout the world. In the Adolfo Lopez Mateos dam in Michoacán, México, this invasive fish has found an appropriate habitat in which a lack of predators and exploitation, a surplus of available food and the presence of parental care, as well 
as a long reproductive season, have produced high recruitment and successful colonization. Locally known as the "bagre armado" or "armoured catfish," it is a by-catch of tilapia fishing and accounts for up to $80 \%$ of total captured fish, thereby affecting the economy of the surrounding communities, which also depend on native species like the Balsas catfish (Ictalurus balsanus) and the redside cichlid (Cichlasoma istlanum). This invasive fish is discarded by fishermen since native people do not consume it, partly due to its appearance. Fishermen commonly discard these fish directly into the water and at landing areas, generating contamination. However, this fish has a high nutritional value including a high percentage of protein in fish muscle (90.1\% of dry weight) and a rich lipid content (fatty acid composition with $39.81 \%$ polyunsaturated fatty acids, including $13.9 \%$ DHA) [2]. Therefore, the utilisation of these fish as a source of food ingredients with added value can result in an improvement of the local economy. A recent study on zebra fish fed with carp by-product demonstrated a reduction in lipid peroxidation in the muscle and brain, which shows the potential of these fish by-products as nutraceuticals [3].

One option is applying an enzymatic hydrolysis for the solubilization of the protein and a further separation step in order to enhance its nutritional and functional value [4]. The insoluble protein can be used as animal feed, whereas the soluble protein can be used as a source of food ingredients of high commercial value or as a nutrient for bacterial fermentation [5,6]. The main proteases involved in the fish hydrolysis of fish protein are papain, pepsin, neutrase, alcalase, protamex, trypsin and pronase [7-9]. Several factors are considered as key to control this complex enzymatic hydrolysis, including the types and concentrations of proteases, $\mathrm{pH}$ and temperature of hydrolysis and the source of protein [10]. Typically fish protein hydrolysis is carried out at neutral or alkaline $\mathrm{pH}$ conditions as acidic conditions generally lead to lower yields and deterioration of amino acids, with a subsequent reduction in nutritional quality.

The aim of this study was to produce hydrolysates from armoured catfish using food-grade proteases (neutrases and alcalases) and investigate process conditions ( $\mathrm{pH}$ and temperature) that led to a high degree of hydrolysis, antioxidant activity, and Angiotensin I-Converting Enzyme (ACE) Inhibitory activity. The antioxidant activity was measured by three different methods (ABTS, FRAP and ORAC) based on different mechanisms with relevance to food and biological systems in order to obtain a more comprehensive assessment of the activity. In addition, the main peptide structures in the hydrolysates were determined in order to gain insight into the structure-activity relationship.

\section{Results}

\subsection{The Degree of Hydrolysis ( $\mathrm{DH} \%)$}

The degree of hydrolysis was determined in order to determine the proteolytic activity of the three ENMEX ${ }^{\circledR}$ proteolytic enzymes at different temperatures and $\mathrm{pH}$ values (Figure $1 \mathrm{~A}-\mathrm{C}$ ) after $2 \mathrm{~h}$ of hydrolysis. For HT, the degree of hydrolysis increased with $\mathrm{pH}$ and the highest degree of hydrolysis was $34.51 \%$ at $\mathrm{pH} 8$ and $55^{\circ} \mathrm{C}$. For PAL the highest degree of hydrolysis was $44.70 \%$ at $\mathrm{pH} 9.0$ and $55^{\circ} \mathrm{C}$ and the degree of hydrolysis decreased with an increase in $\mathrm{pH}$ and temperature. For $\mathrm{PF}$, the maximum degree of hydrolysis was $24.00 \%$, which was achieved at $\mathrm{pH} 7$ and $50{ }^{\circ} \mathrm{C}$. The degree of hydrolysis increased at an alkaline $\mathrm{pH}$. Therefore, the highest degree of hydrolysis was obtained with PAL. However, with this enzyme no maximum was determined as the value of DH\% still increased at the highest $\mathrm{pH}$ tested ( $\mathrm{pH}$ 9). To conclude, the degree of hydrolysis was influenced by the type of enzyme, $\mathrm{pH}$ and temperature. The values obtained here were higher than those reported for muscle fish of different species-for example, 19.3\% degree of hydrolysis in tuna dark muscle hydrolysate with Alcalase and Neutrase [11], 15\% degree of hydrolysis in hydrolysate from yellow stripe trevally meat using Alcalase and Flavourzyme [12] and 40\% degree of hydrolysis in hydrolysate of the muscle of brownstripe red snapper produced by Alcalase or Flavourzyme [13]. 

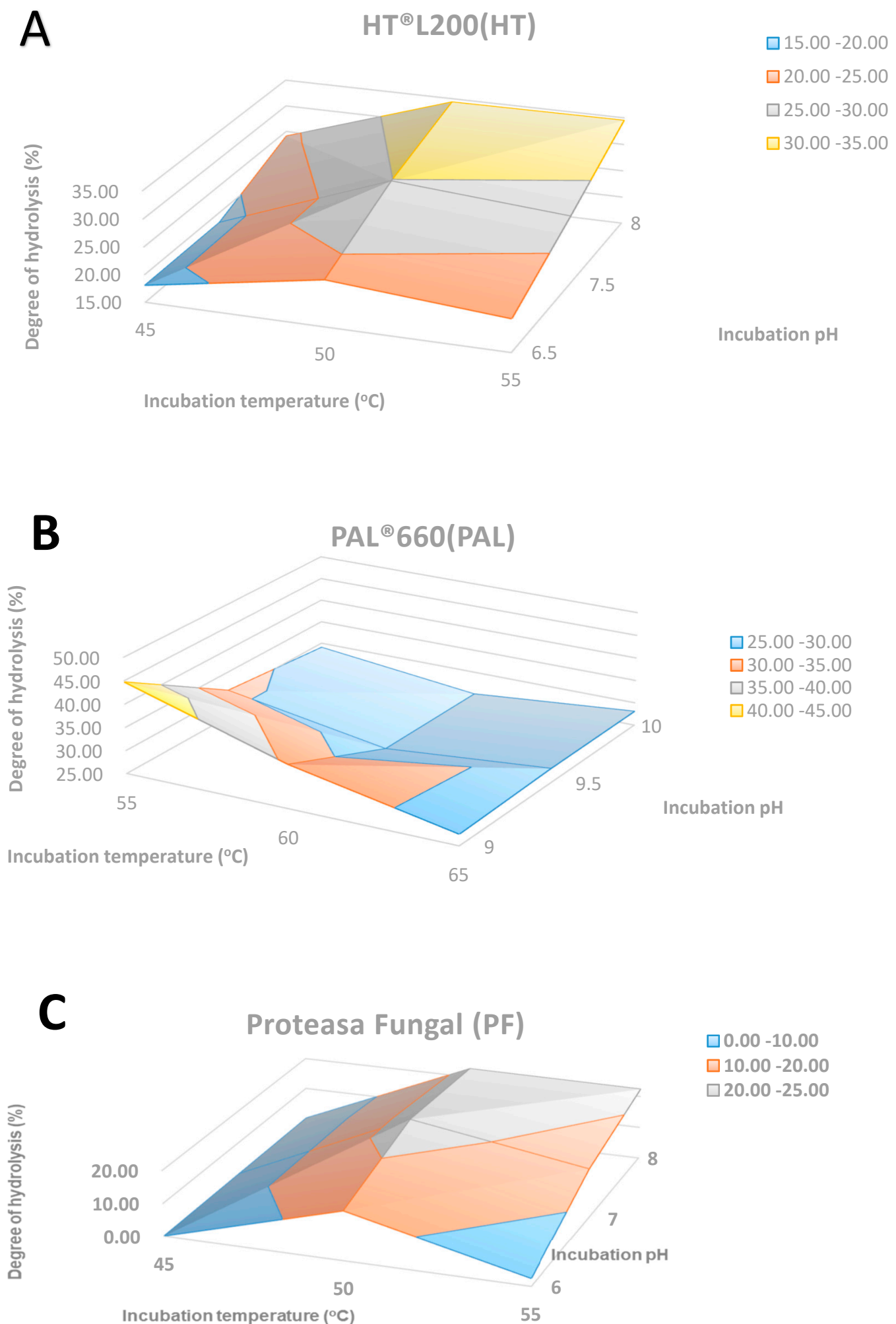

Figure 1. The degree of hydrolysis for each of the enzymes at various $\mathrm{pH}$ values and temperatures of hydrolysis: (A) HT hydrolysate; (B) PAL hydrolysate; (C) PF hydrolysate.

\subsection{The Antioxidant Activity of Hydrolysates}

After producing the hydrolysates of Pterygoplichthys, the bioactivity of these hydrolysates was assessed in order to explore the potential health benefits and/or value enhancement of this product. In this study, the antioxidant activity of Pterygoplichthys hydrolysates was measured by three different 
methods, ABTS, FRAP and ORAC. These methods have been widely used in the assessment of antioxidant activity in food and biological systems; they are based on different mechanisms of reaction and act on different free radicals. ORAC measures the antioxidant inhibition of peroxyl radical-induced oxidations and, thus, reflects classical radical chain breaking antioxidant activity by $\mathrm{H}$ atom transfer [14]. The ferric reducing antioxidant power (FRAP) measures the antioxidant power based on the reduction of $\mathrm{Fe}^{3+}$ (complex ferric ion-TPTZ (2,4,6-tri(2-pyridyl)-1,3,5-triazine)) by the antioxidant [15]. This assay has been used to determine the reducing power in plasma and is a reasonable screen for the ability to maintain redox status in cells or tissues [14]; it is also widely used to assess antioxidant activity in foods as it can be relevant to metal-mediated oxidation of foods; for instance, it has been found to be a good test to asses oxidative deterioration in meat [16]. ABTS has been widely applied to assess antioxidant activity in beverages and foods. In particular, the ORAC and FRAP methods are the most relevant to antioxidant activity in vivo.

\subsubsection{The Antioxidant Activity of Hydrolysates by the ABTS Method}

Figure 2 shows the antioxidant activity of hydrolysates measured as their capacity for scavenging the ABTS radical. The antioxidant activity of HT hydrolysates reached the maximum value at $174.68 \mu \mathrm{mol} / \mathrm{g}$ (Trolox equivalent per gram of fish) (Figure 2A). The antioxidant activity increased from $\mathrm{pH} 6.5$ to 7 but decreased at 8 . The $\mathrm{pH}$ had a stronger effect than the temperature on the antioxidant activity. Briefly, the antioxidant activity increased slightly when the temperature increased but reduced after $50{ }^{\circ} \mathrm{C}$. The antioxidant activity of PAL hydrolysates reached a maximum at $148.14 \mu \mathrm{mol} / \mathrm{g}$ (Figure 2B) and PF hydrolysates at $131.80 \mu \mathrm{mol} / \mathrm{g}$ (Figure 2C). The hydrolysates of HT and PF reached the highest antioxidant activity at the same conditions that led to the highest degree of hydrolysis, $50^{\circ} \mathrm{C} / \mathrm{pH} 7.5$ and $50^{\circ} \mathrm{C} / \mathrm{pH} 7$, respectively, which were mild conditions. However, for PAL hydrolysates the highest antioxidant activity was obtained at more extreme conditions, $65^{\circ} \mathrm{C}$ and $\mathrm{pH} 10$.

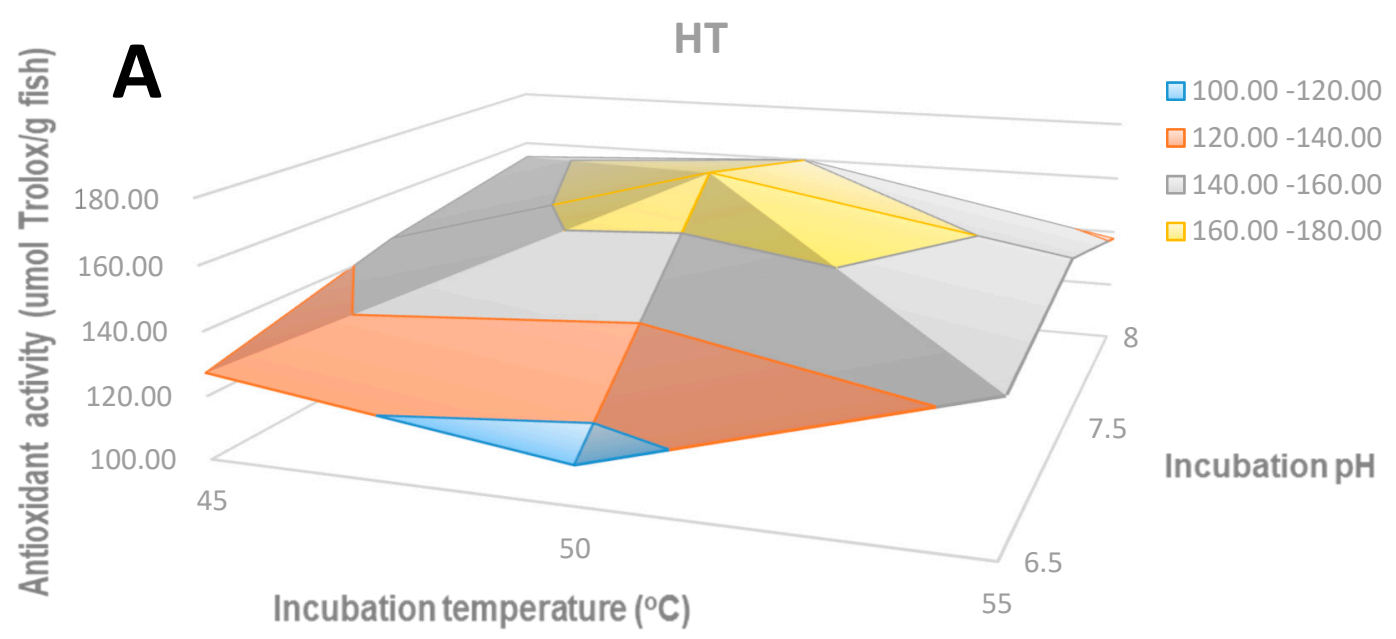

Figure 2. Cont. 

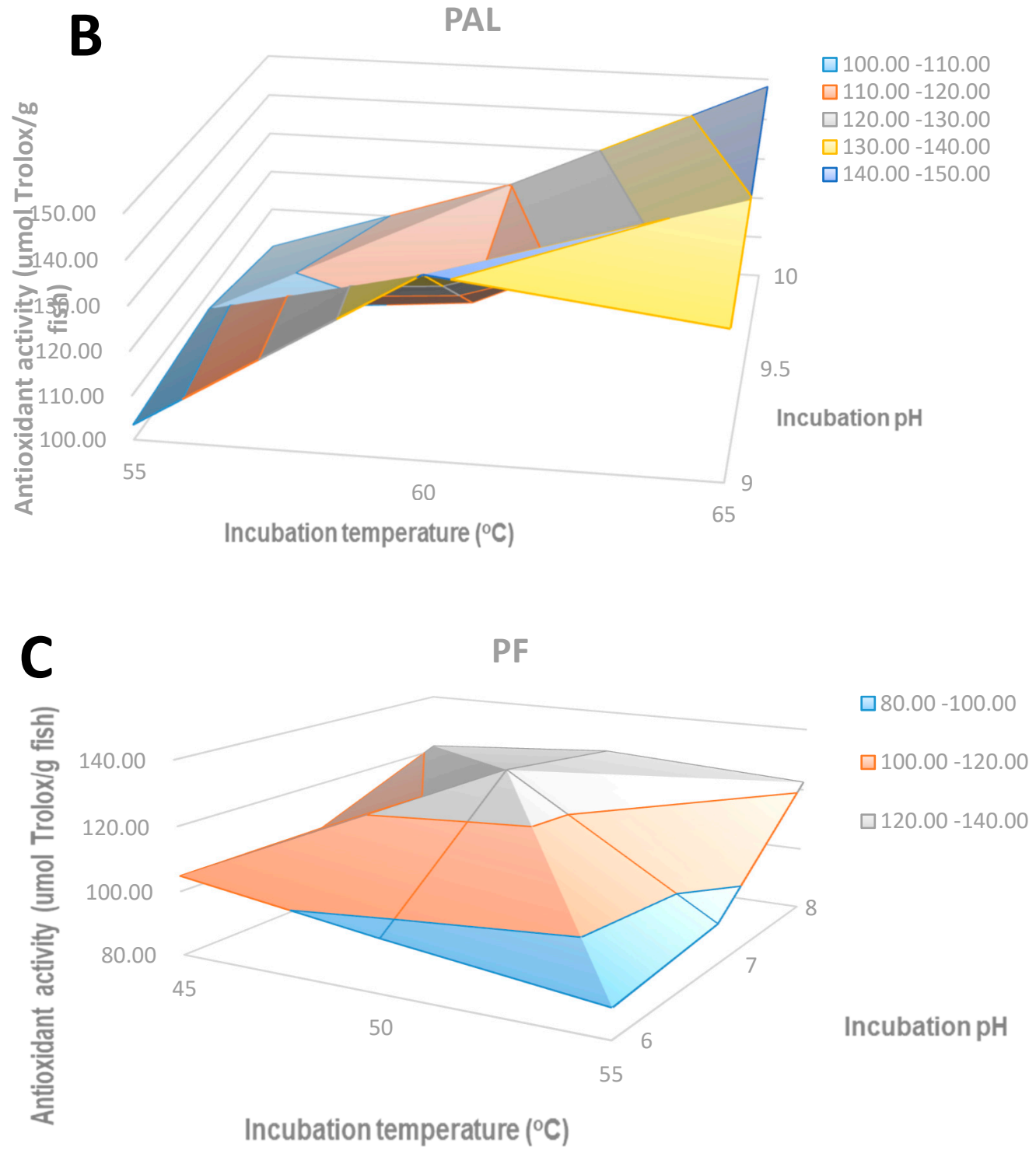

Figure 2. The antioxidant activity of hydrolysates by the ABTS method: (A) HT hydrolysate; (B) PAL hydrolysate; (C) PF hydrolysate.

\subsubsection{The Antioxidant Activity of Hydrolysates by the FRAP Method}

The FRAP method for antioxidant activity relies on the reduction of $\mathrm{Fe}^{3+}$ by the antioxidant and the mechanism of action is based on electron transfer [14]. The antioxidant activity of hydrolysates obtained by the three commercial enzymes at a range of temperatures and $\mathrm{pH}$ values was measured and expressed as the ascorbic acid equivalent. The highest antioxidant activity was obtained with HT, where the highest antioxidant activity (7.59 mg Ascorbic acid equivalent per gram of fish) was obtained at $50{ }^{\circ} \mathrm{C}$ and $\mathrm{pH} 7.5$ (Figure 3). This peak value was obtained in the middle range of both temperature and $\mathrm{pH}$. On the contrary, for the $\mathrm{PF}$ hydrolysates the highest value of antioxidant activity $(3.03 \mathrm{mg} / \mathrm{g})$ was obtained at the highest temperature $\left(55^{\circ} \mathrm{C}\right)$ and $\mathrm{pH}(8)$. For PAL hydrolysates the maximum activity $(5.82 \mathrm{mg} / \mathrm{g})$ was obtained at $60^{\circ} \mathrm{C}$ and $\mathrm{pH} 9.5$. 


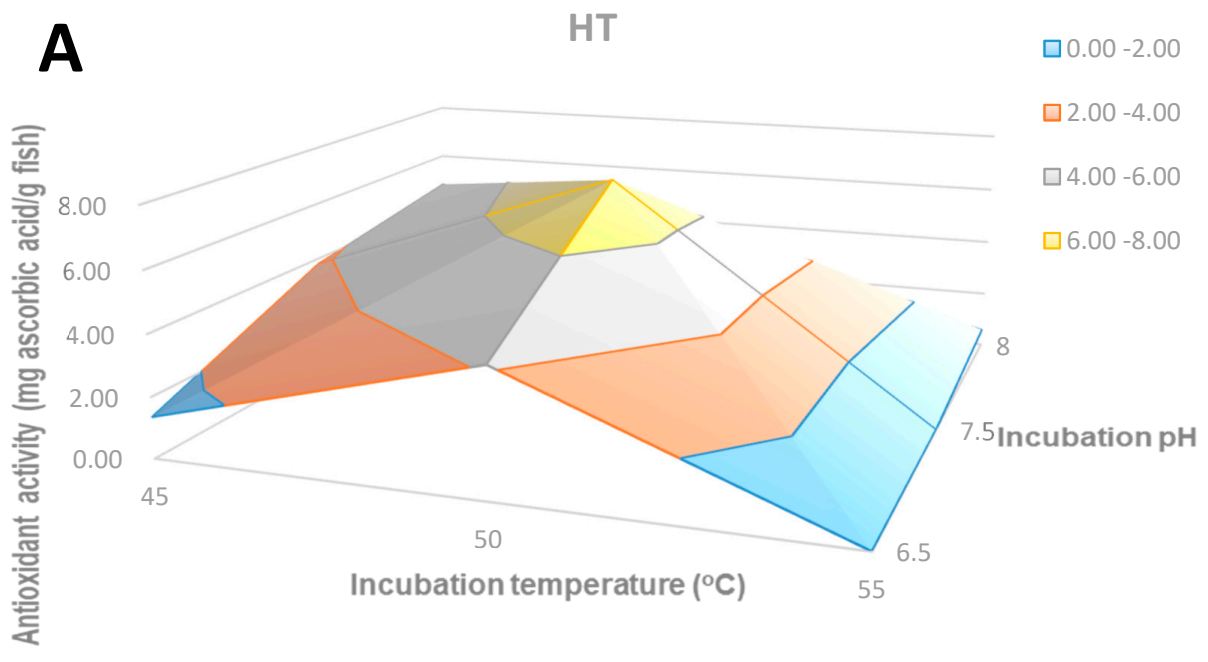

B

PAL
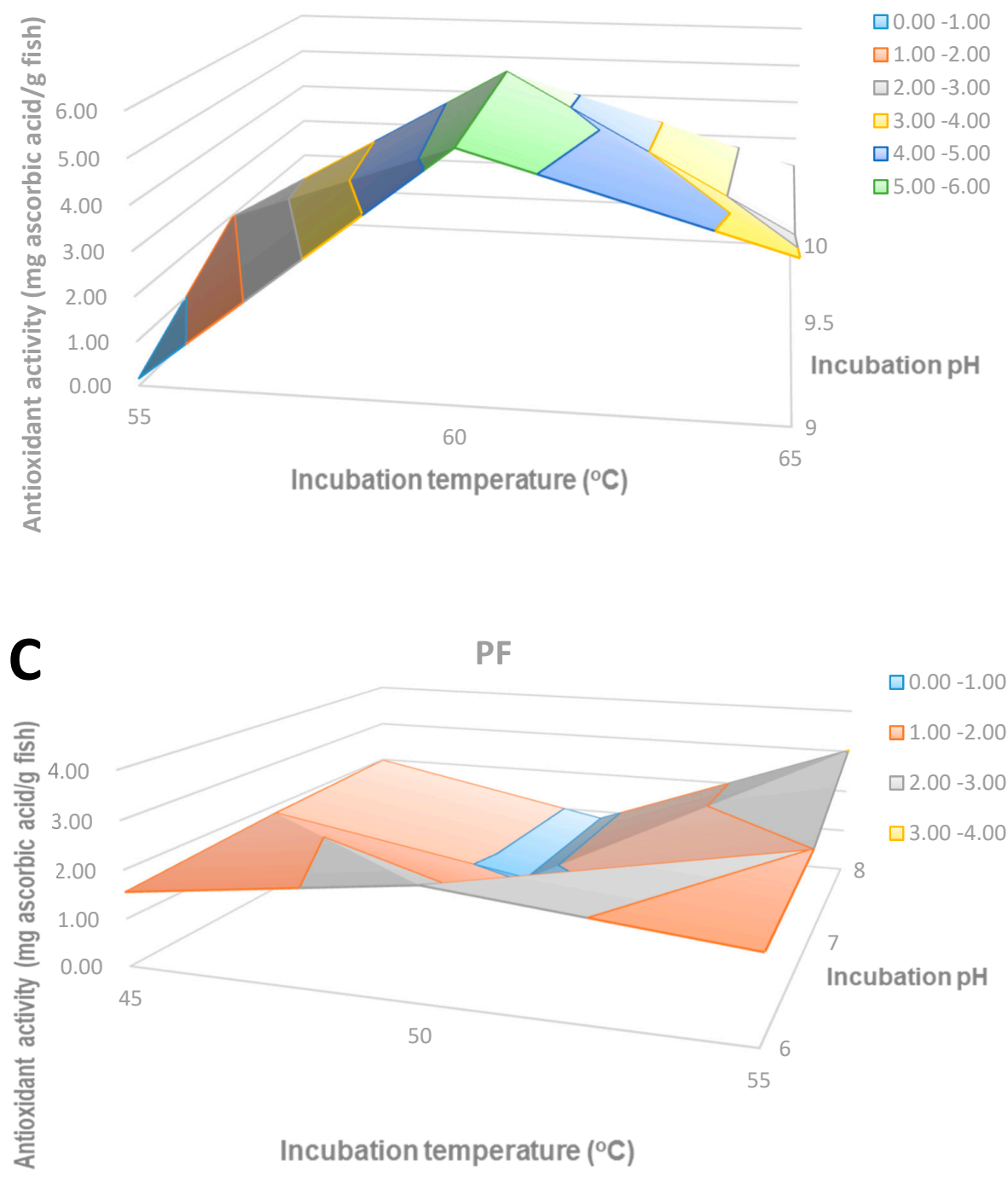

Figure 3. The antioxidant activity of hydrolysates by the FRAP method: (A) HT hydrolysates; (B) PAL hydrolysates; (C) PF hydrolysates. 
2.2.3. The Antioxidant Activity of Hydrolysates by the ORAC Method

This method has been applied for the measurement of antioxidant activity in food, especially beverages [15]. As shown in Figure 4A, the optimum conditions for antioxidant activity by the ORAC method with HT were $\mathrm{pH} 7.5$ and $50^{\circ} \mathrm{C}$. The maximum value was $51.43 \mu \mathrm{mol} / \mathrm{g}$, expressed as Trolox equivalent per gram fish. The antioxidant activity reduced as the temperature increased. Similarly, the antioxidant activity of the hydrolysates by PAL (Figure $4 \mathrm{~B}$ ) reduced as the $\mathrm{pH}$ and temperature were raised, and the highest value was $55.60 \mu \mathrm{mol} / \mathrm{g}$ at $\mathrm{pH} 9$ and $55^{\circ} \mathrm{C}$. A similar phenomenon occurred in the PF hydrolysates (Figure 4C) as the highest antioxidant activity $(13.60 \mu \mathrm{mol} / \mathrm{g})$ was at $\mathrm{pH} 7$ and $45^{\circ} \mathrm{C}$, although it was much lower than that in the HT and PF hydrolysates.

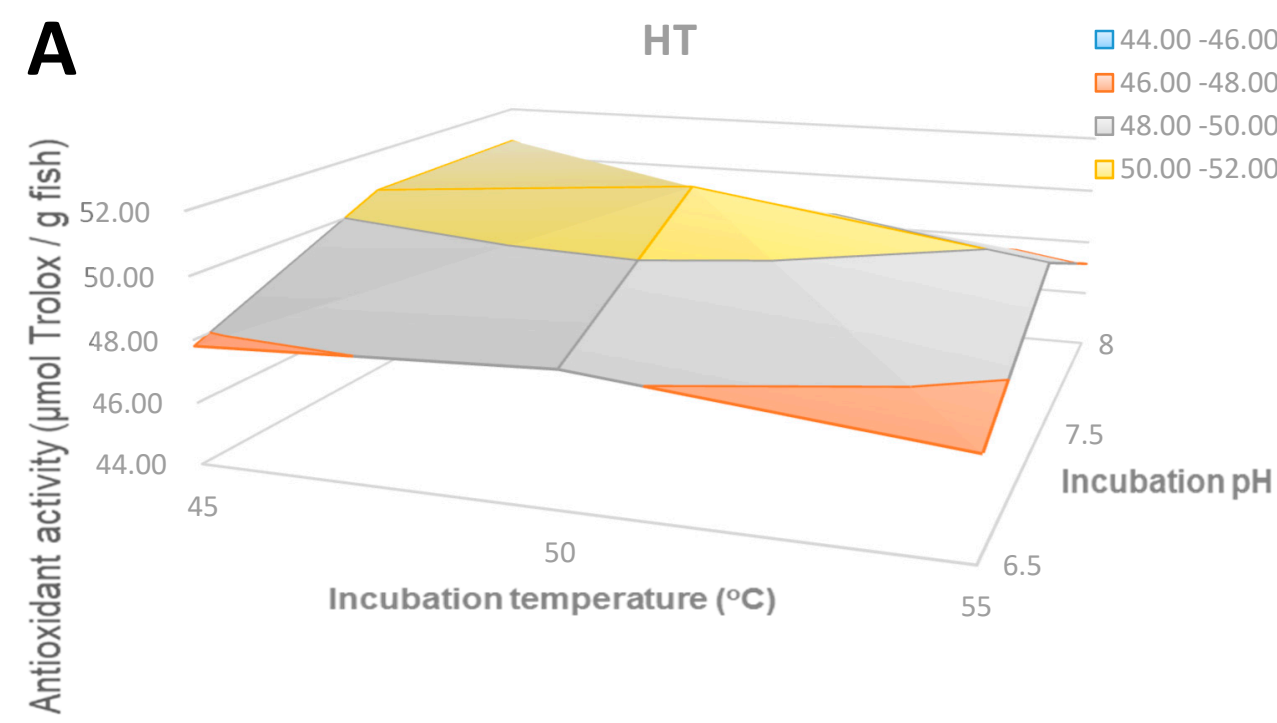

B

PAL

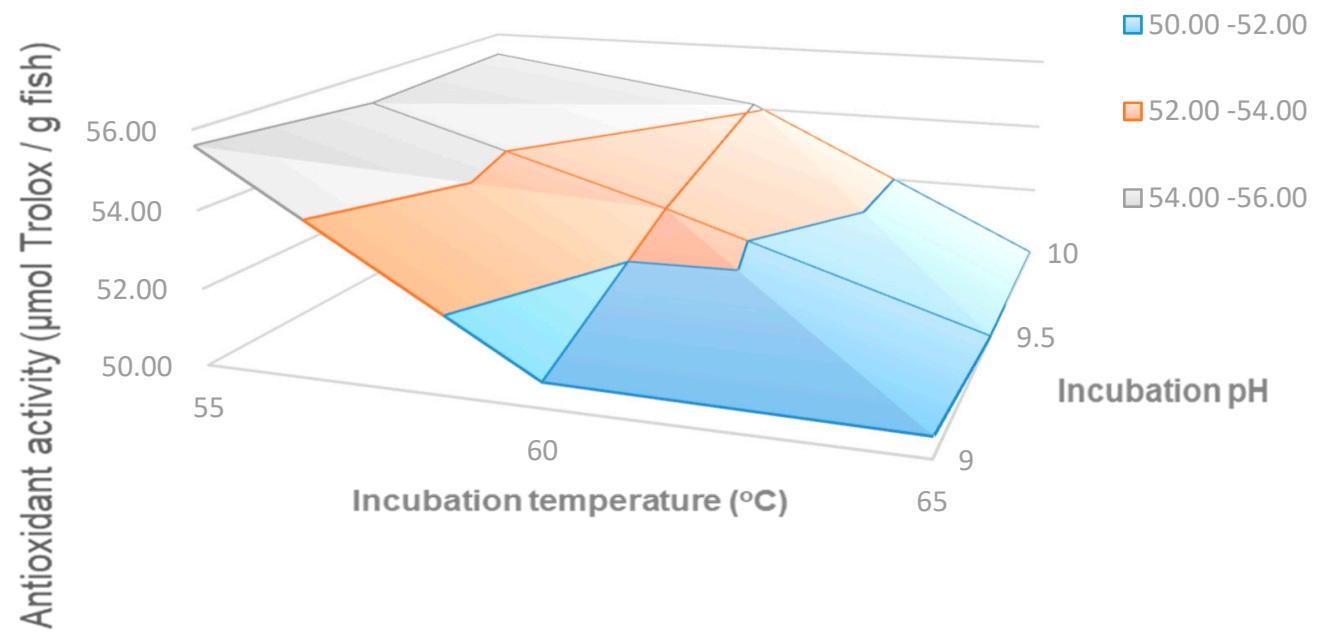

Figure 4. Cont. 


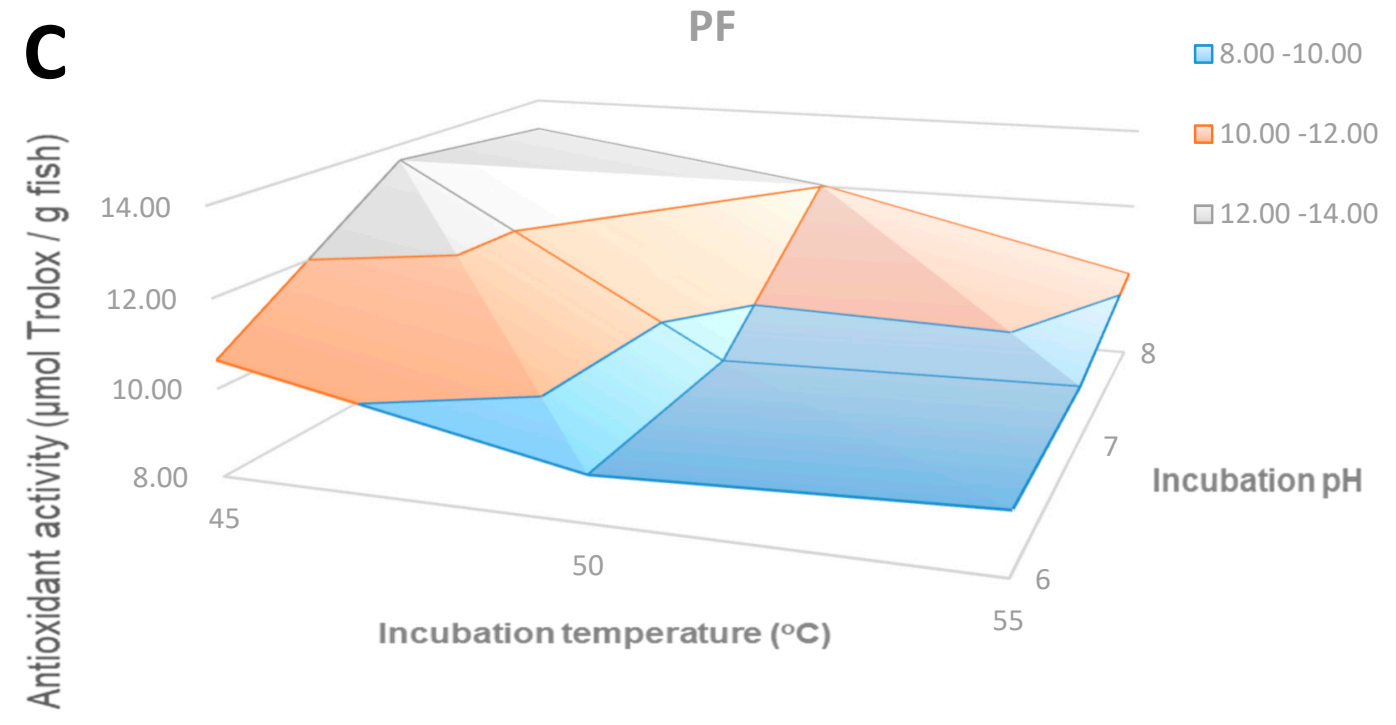

Figure 4. The antioxidant activity of hydrolysates by the ORAC method: (A) HT hydrolysate; (B) PAL hydrolysate; (C) PF hydrolysate.

\subsection{The Angiotensin-I-Converting Enzyme (ACE) Inhibitory Activity of Fish Hydrolysates}

The ACE inhibitory activity of bioactive peptides from Pterygoplichthys hydrolysates produced by three commercial proteolytic enzymes was determined by using FAPGG as the substrate; only the hydrolysate with the highest degree of hydrolysis obtained with each enzyme was assessed. The $\mathrm{IC}_{50}$, defined as the concentration of protein/peptide required to reduce the ACE activity by half, was reported as a measure of the effectiveness of the ACE inhibitor (hydrolysate). The $\mathrm{IC}_{50}$ values were: $11.84 \mathrm{mg} / \mathrm{mL}\left(\mathrm{PAL}\right.$ at $\mathrm{pH} 9.0$ and $\left.55^{\circ} \mathrm{C}\right) ; 11.47 \mathrm{mg} / \mathrm{mL}\left(\mathrm{HT}\right.$ at $\mathrm{pH} 8.0$ and $\left.50^{\circ} \mathrm{C}\right) ; 9.58 \mathrm{mg} / \mathrm{mL}(\mathrm{PF}$ at $\mathrm{pH}$ 7.0 and $\left.50{ }^{\circ} \mathrm{C}\right)$.

\subsection{The Digestibility of the Hydrolysates}

The digestibility of the hydrolysates with the highest degree of hydrolysis was measured by the TCA method. The digestibility of the hydrolysates by HT, PAL and PF were $15.71 \% \pm 2.10$, $15.13 \% \pm 2.38$ and $14.95 \% \pm 2.39$, respectively.

\subsection{Bioactive Peptides}

In Table 1 the main peptide sequences identified in hydrolysates produced by each of the proteases at conditions that led to the highest $\mathrm{DH} \%$ are shown. Only sequences identified with high certainty are included in Table 1, i.e., peptide sequences obtained with a high ion 'score' (how well the spectrum matches the suggested peptide) and low 'expected' values (the probability of obtaining that peptide purely by chance).

The myofibrillar proteins myosin and actin are the main proteins present in meat (muscle). As expected, the main peptide sequences identified matched these proteins (Table 1); however, often multiple proteins matched the same peptide sequence. 
Table 1. Main peptide sequences identified in each of the enzyme's hydrolysates; $\mathrm{Mr}(\mathrm{expt})$ and $\mathrm{Mr}$ (calc) are the experimental and calculated theoretical molecular weights; 'Protein' is the protein matching that peptide.

\begin{tabular}{|c|c|c|c|c|c|c|}
\hline Enzyme & Peptide & $\operatorname{Mr}(\operatorname{expt})$ & Mr(calc) & Score & Expect & Protein \\
\hline \multirow[t]{4}{*}{ PAL } & REELNEIIEEVDEDGSGT & 2032.9123 & 2032.9073 & 100 & $2.7 \times 10^{-5}$ & \multirow{2}{*}{ Troponin C } \\
\hline & REELNEIIEEVDEDGSGTID & 2261.0018 & 2261.0183 & 85 & $7.3 \times 10^{-4}$ & \\
\hline & IEELEEEIEAER & 1487.6950 & 1487.6991 & 88 & $4.8 \times 10^{-4}$ & myosin heavy chain \\
\hline & ККАЕРАРАРАРАРЕ & 1372.7291 & 1372.7350 & 76 & 0.009 & $\begin{array}{l}\text { Embryonic } \\
\text { myosin } \\
\text { light chain }\end{array}$ \\
\hline \multirow[t]{9}{*}{ HT } & LAEKDEEIEQI & 1315.64 & 1315.6507 & 71 & 0.03 & Myosin heavy chain \\
\hline & LAEKDEEIEQIK & 1443.7384 & 1443.7456 & 78 & 0.0056 & \\
\hline & IEELEEEIEAER & 1487.6917 & 1487.6991 & 90 & $2.5 \times 10^{-4}$ & \\
\hline & NSYEEALDHLETL & 1532.6970 & 1532.6994 & 68 & 0.045 & \\
\hline & LESEVEGEQR & $\begin{array}{l}1174.5428 \\
1174.5466\end{array}$ & & 70 & 0.03 & \\
\hline & FDMFDTDGGGDISTK & $\begin{array}{l}1604.6567 \\
1604.6665\end{array}$ & & 109 & $9.5 \times 10^{-7}$ & \\
\hline & REELNEIIEEVDEDGSGTID & $\begin{array}{l}2261.0113 \\
2261.0183\end{array}$ & & 73 & 0.012 & \\
\hline & SQKEDKYEEEI & $\begin{array}{l}1396.6302 \\
1396.6358\end{array}$ & & 82 & 0.015 & \\
\hline & LEKTIDDLEDELYSQ & $\begin{array}{l}1809.8489 \\
1809.8520\end{array}$ & & 98 & $6.2 \times 10^{-5}$ & \\
\hline \multirow{15}{*}{ PF } & TEEMASQDESIAK & 1437.6256 & 1437.6293 & 97 & $3.3 \times 10^{-5}$ & \\
\hline & AQRLQEAEESIEAV & 1571.7776 & 1571.7791 & 71 & 0.029 & \\
\hline & QGEVEDLMIDVERA & 1602.7473 & 1602.7559 & 86 & $7 \times 10^{-4}$ & \\
\hline & RNAEEKAKKAITDAA & 1614.8767 & 1614.8689 & 74 & 0.012 & \\
\hline & LEEAEGTLEHEESKI & 1712.8086 & 1712.8104 & 87 & $7 \times 10^{-4}$ & \\
\hline & EELKKEQDTSAHLER & 1811.8991 & 1811.9013 & 80 & 0.0047 & \\
\hline & LEEAEGTLEHEESKIL & 1825.8829 & 1825.8945 & 72 & 0.026 & \\
\hline & KRQAEEAEEQANTHLS & 1839.8700 & 1839.8711 & 71 & 0.026 & \\
\hline & REQFEEEQEAKAELQ & 1862.8581 & 1862.8646 & 86 & $7.6 \times 10^{-4}$ & \\
\hline & EQQVDDLEGSLEQEKK & 1873.8915 & 1873.8905 & 71 & 0.034 & \\
\hline & AEELKKEQDTSAHLER & 1882.9359 & 1882.9384 & 92 & 0.00031 & \\
\hline & $\begin{array}{l}\text { QARIEELEEEIEAERAA. + } \\
\text { Gln->pyro-Glu (N-term Q) }\end{array}$ & 1967.9345 & 1967.9435 & 78 & 0.0063 & \\
\hline & KQKYEEGQAELEGAQKEA & 2034.9739 & 2034.9857 & 92 & $2.4 \times 10^{-4}$ & \\
\hline & EMEEAQERADIAESQVNK & 2075.9393 & 2075.9429 & 81 & 0.0021 & \\
\hline & KRENKNLQQEISDLTEQI & 2185.1241 & 2185.1338 & 72 & 0.034 & \\
\hline
\end{tabular}


Table 1. Main peptide sequences identified in each of the enzyme's hydrolysates; $\mathrm{Mr}(\mathrm{expt})$ and $\mathrm{Mr}$ (calc) are the experimental and calculated theoretical molecular weights; 'Protein' is the protein matching that peptide.

\begin{tabular}{|c|c|c|c|c|c|c|}
\hline Enzyme & Peptide & $\operatorname{Mr}(\operatorname{expt})$ & Mr(calc) & Score & Expect & Protein \\
\hline & EEGQAELEGAQKEARS & 1730.8073 & 1730.8071 & 86 & $7.5 \times 10^{-4}$ & $\begin{array}{c}\text { Myosin heavy chain, } \\
\text { fast skeletal muscle isoform X1 } \\
\text { [Danio rerio }]\end{array}$ \\
\hline & KMEIDDLSSNMEAVAKS & 1866.8692 & 1866.8703 & 86 & $8.2 \times 10^{-4}$ & $\begin{array}{l}\text { Myosin heavy chain } \\
\text { (Seriola demirili) }\end{array}$ \\
\hline & SYKRQAEEAEEQANTHLS & 2089.9620 & 2089.9664 & 72 & 0.02 & $\begin{array}{l}\text { Myosin heavy chain-2 } \\
\text { [Thunnus orientalis] }\end{array}$ \\
\hline & EADLVQIQGEVDDTVQEA & 1957.9077 & 1957.9117 & 96 & $8.8 \times 10^{-5}$ & $\begin{array}{l}\text { Myosin heavy chain } \\
\text { [Pennahia argentata] }\end{array}$ \\
\hline & KAISEELDHALNDMTSI & 1885.9049 & 1885.9091 & 84 & 0.0017 & $\begin{array}{c}\text { Tropomyosin alpha-1 chain-like } \\
\text { isoform X2 } \\
\text { [Nothobranchius furzeri] }\end{array}$ \\
\hline & KATEDELDKYSEALKDAQEKL & 2423.1937 & 2423.2067 & 88 & $8.4 \times 10^{-4}$ & \\
\hline & RALGQNPTNKDVAK & 1510.8211 & 1510.8216 & 78 & 0.0039 & $\begin{array}{l}\text { Myosin light chain } 1 \\
\text { [Thunnus thynnus] }\end{array}$ \\
\hline & ККАЕРАРАРАРАРЕ & 1372.7315 & 1372.7350 & 76 & 0.0087 & \\
\hline & SSSSLEKSYELPDGQVI & 1837.8938 & 1837.8945 & 71 & 0.032 & $\begin{array}{l}\text { Alpha-smooth muscle } \\
\text { actin-rabbit (fragment) }\end{array}$ \\
\hline & SSSSLEKSYELPDGQVIT & 1938.9372 & 1938.9422 & 71 & 0.038 & \\
\hline & AVFDISNADRLGSSEVDQV & 2020.9632 & 2020.9702 & 82 & 0.0027 & $\begin{array}{c}\text { Creatine kinase M-type } \\
\text { [Gekko japonicus] }\end{array}$ \\
\hline
\end{tabular}

\section{Discussion}

\subsection{Bioactivity}

The hydrolysis of protein by the three enzymes resulted in the generation of peptides with antioxidant activity. PAL produced the hydrolysate with the highest degree of hydrolysis, yet HT produced the hydrolysate with the highest antioxidant activity according to all methods except ORAC (Figure 4); PAL hydrolysate was slightly superior, although similar ORAC results were obtained with HT. These results are in accordance with those reported as the highest degree of hydrolysis was obtained with the alcalase, whilst the highest antioxidant activity was obtained with the neutralase $[17,18]$. Moreover, with HT maximum antioxidant activity was obtained at the same conditions, $\mathrm{pH} 7.5$ and $50{ }^{\circ} \mathrm{C}$, according to the three methods. The mild conditions in which maximum activity were achieved was another advantage of HT compared to PF and PAL enzymes; this is illustrated in Figure 5, where maximum antioxidant activities for each enzyme and conditions are shown for the ABTS method. Overall, the antioxidant activity based on the ABTS method was superior to that reported for other fish hydrolysates, e.g., $48 \mu \mathrm{mol} / \mathrm{g}$ hydrolysate from the unicorn leatherjacket, DH 40\% [19] and was comparable to the value reported for plant-derived extracts, e.g., artichoke extract, $92 \mu \mathrm{mol} / \mathrm{g}$ [20]; blackcurrant extract, 156-196 $\mu \mathrm{mol} / \mathrm{g}$ (results from our group, not published); and grape marc extract, 193-485 $\mu \mathrm{mol} / \mathrm{g}[21]$.

According to the ORAC method, the highest antioxidant activity was found in the HT $(51.43 \mu \mathrm{mol} / \mathrm{g})$ and PAL (55.60 $\mu \mathrm{mol} / \mathrm{g})$ hydrolysates. These activities were much higher than those reported for hydrolysates from alkaline-aided channel catfish by a Bacillus protease $(16 \mu \mathrm{mol} / \mathrm{g}$, which was close to the activity of PF hydrolysates) [22]. Interestingly, the ORAC values obtained here were comparable to those reported for several fruits: in particular, blueberry $(48.26+/-6.49 \mu \mathrm{mol} / \mathrm{g})$, apple $(45.92+/-2.01 \mu \mathrm{mol} / \mathrm{g})$, 
pomegranate $(44.79+/-3.78 \mu \mathrm{mol} / \mathrm{g})$, orange $(28.87+/-7.17 \mu \mathrm{mol} / \mathrm{g})$ and red grape $(26.05+/-4.87 \mu \mathrm{mol}$ of $\mathrm{TE} / \mathrm{g})$ [23].

Based on the above results, it was concluded that HT would be the best enzyme to take the process further.

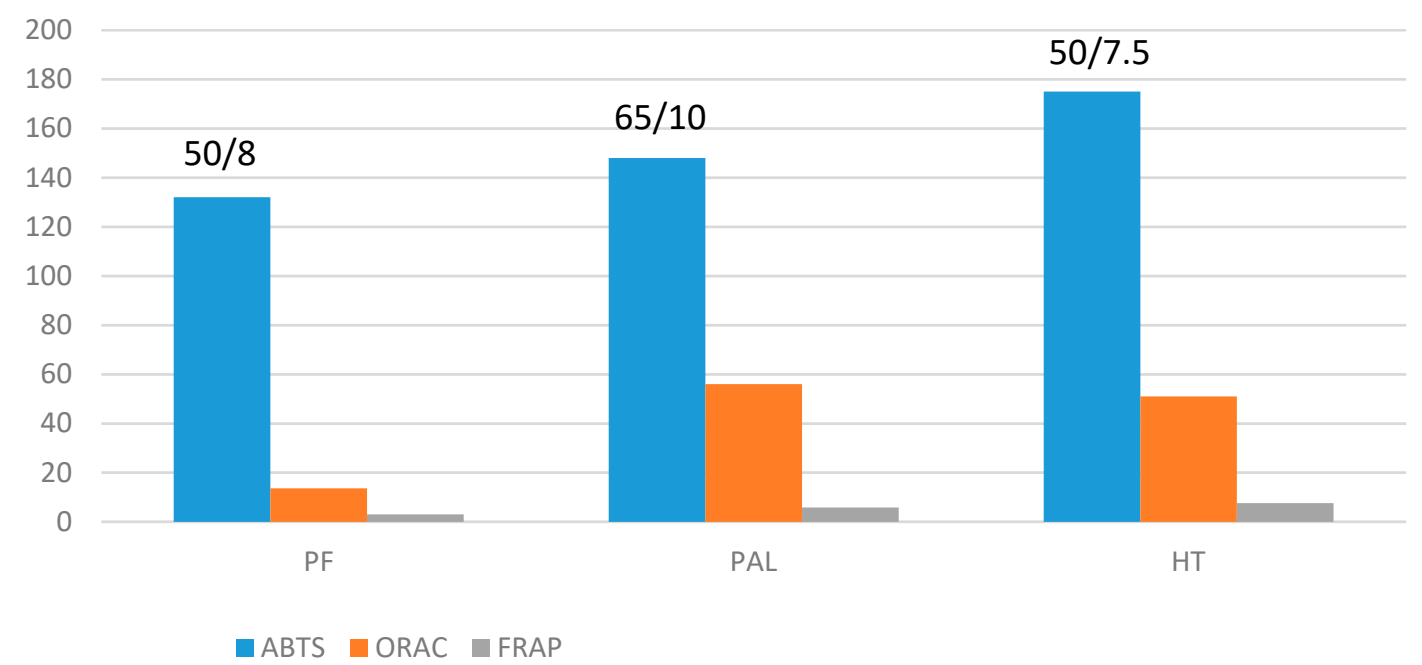

Figure 5. Maximum antioxidant activities obtained for each enzyme according to the three antioxidant activity methods: ABTS ( $\mu$ mol Trolox/g fish), FRAP (mg ascorbic acid/g fish) and ORAC ( $\mu$ mol Trolox/g fish); numbers over ABTS bars indicate $\mathrm{T} / \mathrm{pH}$ conditions for hydrolysate production.

Similar ACE inhibitory activity was obtained with all proteases, and they were close to those reported for hydrolysates from brownstripe red snapper by commercial alcalase (IC50 around $10.0 \mathrm{mg} / \mathrm{mL}$ ) [13] but lower than that obtained from thornback ray (Raja clavata) muscle by Alcalase and Neutrase (around $1.0 \mathrm{mg} / \mathrm{mL}$ ) [18]. However, that hydrolysate was obtained over a longer hydrolysis time $(4 \mathrm{~h})$ than the one produced here $(2 \mathrm{~h})$. Also, the hydrolysates obtained here were raw hydrolysates that underwent no further processing; it is known that smaller peptides have higher ACE inhibitory activity and, therefore, further processing by ultrafiltration can render hydrolysates more potent.

\subsection{Peptide Structure-Activity Relationship}

The exact mechanism of antioxidant activity by peptides is not fully understood, yet they have been shown to act as lipid peroxidation inhibitors, scavengers of free radicals and chelators of transition metal ions [24].

Hydrophobic amino acids such as the aliphatic amino acids (Val (V), Leu (L) and Ileu (I)) will enhance the solubility of peptides in lipids and will facilitate access to hydrophobic radicals and hydrophobic PUFAs [24]. Also, aromatic amino acids (His (H) or Tyr (Y)) can donate protons to electron-deficient radicals, which results in them having radical scavenging properties. Acidic and basic groups in the side chain of amino acids (Asp (D), Glu (E), Hys (H), Arg (R), Lys (K)) can act as metal chelators and $\mathrm{H}$ donors.

The highest antioxidant activity was found in the hydrolysate by HT (Figure 5). It is interesting to note that most of the peptides identified in this hydrolysate (Table 1 ) contain several acidic amino acids in their sequences: in particular, glutamic acid (E) and aliphatic amino acids (Ala(A), Ileu (I), Leu (L)). These sequences were found in both PAL and HT hydrolysates, which had the highest FRAP activity. In particular, the sequence IEE(E) is repeated in several peptides in both hydrolysates (Table 1). This combination of aliphatic and acid amino acids was also found in the peptide LEELEEELEGCE from frog skin, which showed high antioxidant activity [17]. According to these authors, the IC50 (concentration of peptide at 50\% inhibition) for the purified peptide against a range of free radicals was from 12.8 to $32.6 \mu \mathrm{M}$; this would be equivalent to about $1000 \mu \mathrm{M}$ Trolox for $50 \%$ inhibition against 
ABTS radical. It is expected that acidic amino acids would be effective at iron reduction (as measured by FRAP), in a similar manner to ascorbic acid [25]

On the other hand, the peptides in the PF hydrolysate contain more aromatic amino acids than the peptides in the other two hydrolysates and some peptides rich in hystidine $(\mathrm{H})$. This hydrolysate had the lowest FRAP activity, which correlates well with the lower presence of acidic amino acids in the peptide sequences as compared to HT and PAL hydrolysates.

\section{Materials and Methods}

\subsection{Materials}

The Pterygoplicgthys samples are supplied by the University of Michoacan of San Nicolas de Hidalgo (Morelia, Mexico). The enzymes were supplied by ENMEX (Tlalnepantla de Baz, Mexico): two neutrases, HT Proteolitic ${ }^{\circledR}$ L200 (HT), and Proteasa Fungal (PF) and one alcalase, PAL ${ }^{\circledR} 660$ (PAL). The following chemicals were purchased from Sigma Aldrich ${ }^{\circledR}$ (Gillingham, UK): Bis-tris Propane (B6755); O-phthaldialdehyde (OPA, P1378); Sodium-dodecyl-sulphate (SDS) (L3771); Dithiothreitol 99\% (DTT, D0632); Potassium persulfate (216224) was purchased from Sigma Aldrich ${ }^{\circledR} ; 2,2^{\prime}$-Azino-bis(3-ethylbenzothiazoline-6-sulfonic acid) diammonium salt (ABTS, A1888); 2,4,6-Tris(2-pyridyl)-s-triazine (TPTZ, T1253); Ferric Chloride Hexahydrate (F2877); Sodium Acetate Trihydrate (S8625); Glacial Acetic Acid (320099); Disodium fluorescein (F6377); 2,2'-Azobis(2-methylpropionamidine) dihydrochloride (AAPH, 440914); Sodium chloride $[\mathrm{NaCl}]>99.5 \%$ (S7653); Tris (hydroxymethyl) methylamine (T1503); Angiotensin-converting enzyme (ACE, A6778; Hydrochloric acid 36.5-38.0\%, (H1758); FAPGG-N-[3-(2-furyl)acryloyl]-Phe-Gly-Gly $\geq 98 \%$ (F7131); Glycerol solution 86-89\% (49781); Trichloroacetic acid (TCA, T6399).

\subsection{Methods}

\subsubsection{The Preparation and Pre-Treatment of Fish Protein Hydrolysis}

The preparation of armoured catfish (Pterygoplichthys disjunctivus) hydrolysates is described in Figure 6. Five grams of fish fillet were cut into small pieces and added into $50 \mathrm{~mL} 0.1 \mathrm{M}$ Bis-tris Propane buffer ( $\mathrm{pH} 11)$. Then the $\mathrm{pH}$ of each sample was adjusted to the target $\mathrm{pH}$ as described in Table 2. The $0.2 \% w / v(v / v)$ enzyme was added into the sample and the incubation started at a specific temperature for $120 \mathrm{~min}$. Every $30 \mathrm{~min}$, the $\mathrm{pH}$ of the sample was recorded and adjusted back to the starting $\mathrm{pH}$. At the end of hydrolysis, the $\mathrm{pH}$ was measured and hydrolysis was ended by immersing the sample in a $90^{\circ} \mathrm{C}$ water bath for $10 \mathrm{~min}$ to inactivate the enzyme (note: the temperature of the sample reached $85^{\circ} \mathrm{C}$ ). The $\mathrm{pH}$ of the sample was changed to $\mathrm{pH} 7$. The sample was cooled down in an ice bath to room temperature and centrifuged at $4000 \mathrm{~g}$ at $10^{\circ} \mathrm{C}$ for $20 \mathrm{~min}$ in a Thermo Multifuse 3SR+ (Thermo Fisher Scientific, Hemel Hempsted, UK). The supernatant was collected in a 5-mL sterile plastic bottle and stored at $-20^{\circ} \mathrm{C}$ for further analysis. 


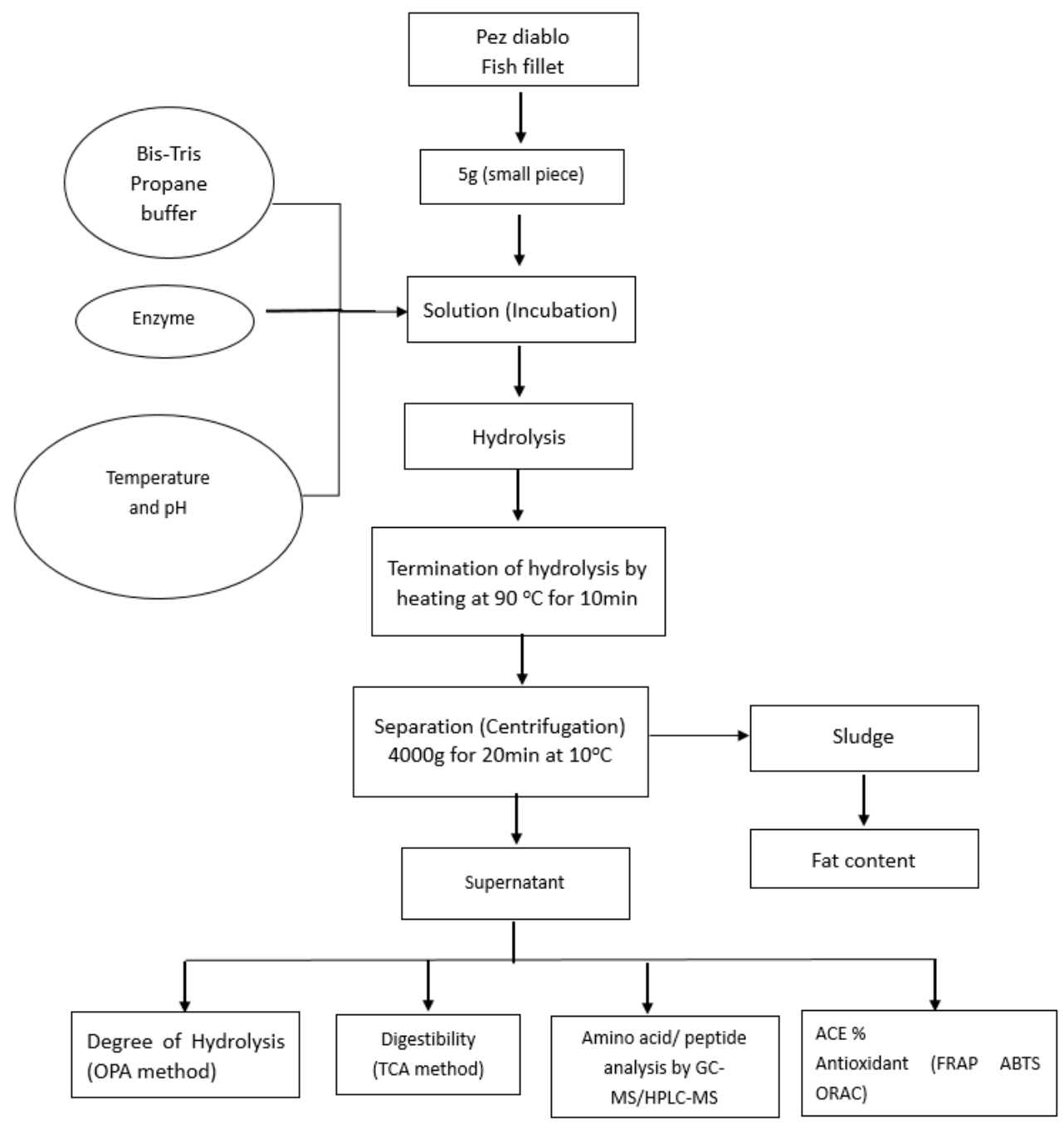

Figure 6. Process followed for the preparation of Pterygoplichthys disjunctivus hydrolysates.

Table 2. Conditions for each of the enzymes.

\begin{tabular}{|c|c|c|c|c|c|c|c|c|}
\hline Enzyme & \multicolumn{3}{|c|}{ Temperature $\left({ }^{\circ} \mathrm{C}\right)$} & \multicolumn{3}{|c|}{$\mathrm{pH}$} & $\# \%(w / v)$ & Time (min) \\
\hline HT PROTEOLITIC ${ }^{\circledR}$ L 200 & 45 & 50 & 55 & 6.5 & 7.5 & 8.0 & $0.2 \%$ & 120 \\
\hline PAL ${ }^{\circledR} 660$ & 55 & 60 & 65 & 9.0 & 9.5 & 10.0 & $0.2 \%$ & 120 \\
\hline Proteasa Fungal & 45 & 50 & 55 & 6.0 & 7.0 & 8.0 & $0.2 \%$ & 120 \\
\hline
\end{tabular}

$\# \% w / v$ is the enzyme (mass) to buffer solution volume ratio as a percentage.

\subsubsection{Experimental Design}

A $3^{2}$ factorial design was applied where the two dependent variables were $\mathrm{pH}$ and temperature and each was studied at three levels $(-1,0,1)$; the experimental conditions are shown in Table 2 . Each experiment was carried out once for each enzyme, but the antioxidant activity was measured in triplicate and the ACEi\% in duplicate.

\subsubsection{Determination of the Degree of Hydrolysis}

The degree of hydrolysis was determined by applying the o-phthaldialdehyde (OPA) method [26] with some modifications. The concentration of samples was kept between 250 and $500 \mu \mathrm{g} \mathrm{mL}^{-1}$. To prepare $200 \mathrm{~mL}$ of solution, $7.620 \mathrm{~g}$ of di-sodium tetraborate decahydrate and $200 \mathrm{mg}$ of sodium-dodecyl-sulfate (SDS) were dissolved completely in $150 \mathrm{~mL}$ of water until homogenised 
in a flask of $250 \mathrm{~mL}$. Separately, $160 \mathrm{mg}$ of $\mathrm{O}$-Phthaldialdehyde (OPA) were dissolved in $4 \mathrm{~mL}$ of ethanol in a $10-\mathrm{mL}$ flask then transferred to the solution mentioned above, rinsing the small flask completely with deionized water. Then $176 \mathrm{mg}$ of Dithiothreitol 99.0\% (DTT) were added to the solution and stirred; this was transferred into a 200-mL volumetric flask and filled up to $200 \mathrm{~mL}$ with deionized water. Standard or samples $(200 \mu \mathrm{L})$ were added into $1.5 \mathrm{~mL}$ OPA reagent in 2-mL acryl cuvettes and after 2 min incubation the absorbance was measured by a UV-Vis Spectrophotometer (Ultrospec (R) 1100 pro, GE Healthcare, Amersham, UK) at $340 \mathrm{~nm}$.

Deionised water was used as a blank and a serine dilution was used as standard. The DH was calculated using the following equation:

$$
D H \%=\frac{h}{h_{t o t}} \times 100 \%,
$$

where $D H \%$ is the degree of hydrolysis in percentage, $h\left(m e q v g^{-1}\right)$ is the number of hydrolysed bonds and $h_{t o t}$ is the total number of peptide bonds per protein equivalent; $h_{t o t}$ is dependent on the protein source and for fish, $h_{t o t}$ is 8.6 meqv $g^{-1}$. The value of $\mathrm{h}$ was obtained by applying the equations below:

$$
\begin{gathered}
h=\frac{\left(\text { Serine } \cdot N H_{2}-\beta\right)}{(\alpha)} \\
\text { Serine } \cdot N H_{2}=\frac{\left(O D_{\text {sample }}-O D_{\text {blank }}\right)}{\left(O D_{\text {standard }}-O D_{\text {blank }}\right)} * 0.9516 \text { meqv } L^{-1} \times \frac{D}{P}
\end{gathered}
$$

where serine- $\mathrm{NH}_{2}=$ meqv serine $\mathrm{NH}_{2} \mathrm{~g}^{-1}$ protein; $\mathrm{D}=$ dilution factor $\mathrm{P}=$ protein concentration in sample $\left(\mathrm{g} \mathrm{L}^{-1}\right)$.

\subsubsection{Determination of Antioxidant Activity of Hydrolysates}

The ABTS Free Radical Scavenging Activity Assay

The total antioxidant activity of samples was measured by ABTS assay at $734 \mathrm{~nm}$, with some modifications from that reported [27]. The $\mathrm{ABTS}^{\bullet+}$ stock solution was prepared by mixing $5 \mathrm{~mL}$ ABTS solution $(7 \mathrm{mM})$ and $88 \mu \mathrm{L}$ potassium persulfate $\left(140 \mathrm{mM} \mathrm{K} \mathrm{S}_{2} \mathrm{O}_{8}\right)$ solution together. Then, the mixture was stored in the dark at room temperature for at least $16 \mathrm{~h}$ prior to use. The working solution of the $\mathrm{ABTS}^{\bullet+}$ was obtained by diluting the $\mathrm{ABTS}^{\bullet+}$ stock solution with phosphate-buffered saline (PBS pH 7.4) to an absorbance of $0.70 \pm 0.02$ at $734 \mathrm{~nm}$. Twenty microliters of samples were added into $2 \mathrm{~mL} \mathrm{ABTS}^{\bullet+}$ working solution, and the solution was homogenised by $1 \mathrm{~min}$ vortex. The solution was then incubated in the dark for $6 \mathrm{~min}$, and the absorbance $\left(\mathrm{ABS}_{\text {sample/standard }}\right)$ was recorded at $734 \mathrm{~nm}$ using a UV-Vis Spectrophotometer (Ultrospec ${ }^{\circledR} 1100$ pro). The absorbance of the ABTS ${ }^{\bullet+}$ working solution was measured at the same wavelength and used as a control $\left(\mathrm{ABS}_{\text {control }}\right)$. The PBS was used as a blank. The (scavenging) activity was measured based on the difference between $\mathrm{ABS}_{\text {control }}$ and

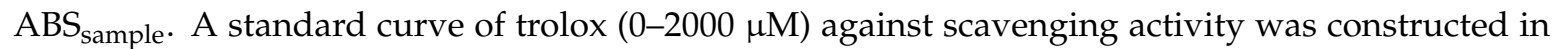
order to relate scavenging activity to Trolox equivalents. The antioxidant activity was expressed as $\mu \mathrm{mol}$ Trolox equivalent/g fish.

\section{The Ferric Reducing Antioxidant Power (FRAP) Assay}

The total antioxidant activity of samples was determined through ferric reducing antioxidant power (FRAP) [28]. The stock solution of FRAP method included: $25 \mathrm{~mL}$ acetate buffer (300 mM), $2.5 \mathrm{~mL} \mathrm{2,4,6-tripyridyl-s-triazine} \mathrm{(TPTZ)} \mathrm{solution}(10 \mathrm{mM}$ in $40 \mathrm{mM} \mathrm{HCl})$, and $2.5 \mathrm{~mL}$ ferric chloride hexahydrate aqueous solution $(20 \mathrm{mM})$. Then, $10 \mu \mathrm{L}$ of the sample/standard were added into $300 \mu \mathrm{L}$ FRAP reagent in a microcentrifuge tube and vortexed for $10 \mathrm{~s}$. Then $100 \mu \mathrm{L}$ of this mixture, in triplicate, were transferred into the microwell plate (96-well, NUNC, FB) and absorbance was measured at $595 \mathrm{~nm}$ by a computer-controlled Tecan Microplate reader (Tecan Ltd., Reading, UK). Results were expressed 
as ascorbic acid equivalent (AAE) using an ascorbic acid $(0.001761 \mathrm{mg} / \mathrm{mL}-0.1761 \mathrm{mg} / \mathrm{mL})$ standard curve (The absorbance $=1.8877 \times A$ A concentration $-0.0013, R^{2}=0.9923$ ).

The Oxygen-Radical Absorbing Capacity (ORAC) Assay

The total antioxidant activity of samples was also measured by oxygen-radical absorbing capacity (ORAC) method, based on previously reported methods [29,30]. A 96-well plate and a Tecan Genius plate reader were used for the fluorescence measurements. The emission and excitation wavelengths were set to 535 and $485 \mathrm{~nm}$, respectively, at $37^{\circ} \mathrm{C}$. Twenty-five microliters of the samples were mixed with $150 \mu \mathrm{L}$ disodium fluorescein ( $96 \mathrm{nM}$ in phosphate buffer $\mathrm{pH}$ 7.4). Then, a volume of $75 \mu \mathrm{L}$ 2,2'-Azobis(2-amidinopropane) dihydrochloride (AAPH, $153 \mathrm{Mm}$ kept in ice) was added to initiate the oxidation reaction. The kinetic fluorescence reading of the samples was recorded for 30 cycles with a 60 s per cycle setting. The antioxidant capacity was expressed as the area under the curve (AUC) by applying Equation (4) below:

$$
\mathrm{AUC}=1+\mathrm{RFU} 1 / \mathrm{RFU} 0+\mathrm{RFU} 2 / \mathrm{RFU} 0+\mathrm{RFU} 3 / \mathrm{RFU} 0+\ldots+\mathrm{RFUn} / \mathrm{RFU} 0
$$

where $\mathrm{RFU}_{0}=$ relative fluorescence units at time point zero; $\mathrm{RFU}_{\mathrm{n}}=$ relative fluorescence units at time points;

A Trolox standard solution and subsequent dilutions $(3.125-50 \mu \mathrm{M})$ were prepared to construct a calibration curve and PBS buffer was used as a blank. The antioxidant capacity of the sample was expressed as Trolox equivalents ( $\mu \mathrm{mol}$ Trolox/g fish).

4.2.5. Determination of the Angiotensin-I-Converting Enzyme (ACE) Inhibitory Activity of Fish Hydrolysates

The ACE inhibitory activity (ACEi\%) of the fish protein hydrolysates was determined according to the methods reported [31,32] and with some modifications. The tripeptide $N$-[3-(2-furyl) acryloyl]-Lphenylalanyl-glycyl-glycine (FAPGG) was used as the substrate of the interaction with ACE in a 96-well microplate at $37^{\circ} \mathrm{C}$. Briefly, $150 \mu \mathrm{L}$ of $88 \mathrm{mM}$ FAPGG in Tris- $\mathrm{HCl}(50 \mathrm{mM}, \mathrm{pH} 7.5$ and $300 \mathrm{mM} \mathrm{NaCl})$ buffer were mixed with $10 \mu \mathrm{L}$ of ACE enzyme $(0.25 \mathrm{mU}$ in $50 \%$ Tris- $\mathrm{HCl}$ buffer and $50 \%$ glycerol) and $10 \mu \mathrm{L}$ of the sample. The kinetics of absorbance of the mixture was monitored at wavelength $340 \mathrm{~nm}$ for $30 \mathrm{~min}$ at 1-min interval by the Tecan plate reader. The slope of decreasing absorbance of the samples was the indicator of the enzyme activity; therefore, the inhibitory activity of each hydrolysate was calculated by Equation (5):

$$
\text { ACE Inhibitory }(\%)=\left(1-\frac{\rho_{i}}{\rho_{0}}\right)
$$

where $\rho_{i}$ is the slope in the presence of hydrolysate (inhibitor) and $\rho_{0}$ is the slope with deionized water. Also, in order to compare different inhibitors (hydrolysates), the $\mathrm{IC}_{50}$ value, which is defined as the protein concentration required to inhibit $50 \%$ of the ACE enzyme activity, was determined.

\subsubsection{The Digestibility of the Hydrolysates}

The in vitro digestibility of the sample was determined by previously reported methods [33,34]. The hydrolysate was mixed with $20 \%$ trichloroacetic in the ratio of 50:50 and then incubated at room temperature for $30 \mathrm{~min}$. After incubation, the sample was centrifuged for $10 \mathrm{~min}$ at $4{ }^{\circ} \mathrm{C}$ and $3000 \mathrm{~g}$. The supernatant was collected and the soluble protein concentration was determined by bicinchoninic acid assay. The digestibility of the hydrolysate was expressed as the percentage of soluble protein in relation to total protein.

Total protein in fish was measured as $19.8 \%$ wet weight. Protein determination was carried out through the evaluation of the total nitrogen using a Scorpio Scientific Kjeldahl unit (Neocitec, Mexico City, Mexico) and following the certified method NMX-F-608-NORMEX-2011. The conversation factor 
was 6.25. The sample $(1 \mathrm{~g})$ was subjected to acid digestion using sulfuric acid; the product was taken to an automatic distiller. The distilled sample was titrated with $0.1 \mathrm{~N}$ hydrochloric acid.

\subsubsection{Identification of Peptides}

Hydrolysates produced by each of the enzymes at the conditions that led to maximum hydrolysis were chosen for further analysis to identify the main peptide sequences.

Samples $(10 \mu \mathrm{L})$ were injected on a Thermo Scientific Accela HPLC system interfaced to a Thermo Scientific LTQ Orbitrap XL mass spectrometer. The column was a Thermo Scientific Hypersil Gold C18 $50 \times 2.1 \mathrm{~mm}$ with particles of 1.9 microns in size and pores of $175 \AA$ A. Mobile Phase A was water and Mobile Phase $B$ was acetonitrile; both contained $0.1 \%$ formic acid. The gradient was $0-2$ min held on $5 \% \mathrm{~B} ; 2-20 \mathrm{~min} 5-20 \% \mathrm{~B} ; 20.1-23 \mathrm{~min}$ held on $80 \% \mathrm{~B} ; 23.1-30 \mathrm{~min}$ held on $5 \% \mathrm{~B}$. An electrospray ionisation (ESI) source operating in positive ion mode was used. The salient source settings were: Capillary temperature $300{ }^{\circ} \mathrm{C}$, Sheath and Aux nitrogen gas flow 45 and 10 arbitrary units, respectively. Source voltage; $4 \mathrm{kV}$, Capillary voltage; 31 , Tube Lens; 131 . The instrument was operating a data-dependent acquisition (DDA). Scan event 1 was acquiring full-scan MS over the $m / z$ range 400-2000, at resolution 30,000 in the Orbitrap. Scan event 2 was acquiring LTQ ion trap Collision-Induced Disassociation (CID) of significant multiply charged peaks found in scan event 1 , which were scanned out in the LTQ ion trap.

Mascot Generic Format (MGF) files were generated from the Thermo Raw files using ProteoWizard 3.0.11148 32 bit and these were searched using an in-house Mascot server v2.5.0 (Matrix Science Ltd., London, UK). Search parameters were: peptide mass 10 ppm, fragment mass 0.6 Da; No enzyme; Variable modifications: Acetyl (Protein $N$-term),Gln->pyro-Glu ( $N$-term Q),Oxidation (M); Database: NCBInr 20160712; Taxonomy: Chordata (vertebrates and relatives). Reports were formatted with the "expected cutoff" set to 0.05 .

\subsubsection{Statistical Analysis}

All the measurements were carried out at least in duplicate. The analysis of variance was done by XLSTAT v20.1 for comparison among samples with different treatments (i.e., different enzymes and/or the same enzyme but different $\mathrm{pH}$ and temperature conditions). The confidence level was set to $p \leq 0.05$.

\section{Conclusions}

For the first time, the production of a protein hydrolysate from armoured catfish (Pterygoplichthys disjunctivus) by a range of proteases has been investigated. High antioxidant activity was obtained in the hydrolysates produced by the three enzymes. In particular, HT led to the highest antioxidant activity according to the ABTS and FRAP methods and almost the same as PAL according to the ORAC method. Moreover, a further advantage of using HT was that the best results were obtained under mild temperature and $\mathrm{pH}$ conditions. Interestingly, the ORAC values obtained here were higher than others previously reported for fish hydrolysates and similar to those reported for fruits such as blueberries, apples and oranges. Moreover, both PAL and HT hydrolysates contained peptide sequences rich in glutamic acid and aliphatic amino acids such as alanine, leucine and isoleucine. In particular, the sequence IEE(E) was present in several peptides in both hydrolysates; this sequence may be partly responsible for the high antioxidant activity, particularly for the activity based on the iron reducing power (FRAP method). Overall, these results show that this underused fish is an important source of antioxidant peptides that can be developed further as food supplements and/or natural antioxidants in food formulations. 
Author Contributions: Conceptualization, P.J. and C.S.A.; methodology, Y.G., P.J., C.S.A., J.F.M. and N.M.; validation, Y.G., N.M. and P.J.; formal analysis, Y.G., N.M. and P.J.; investigation, Y.G. and P.J.; resources, P.J., J.F.M. and C.S.A.; data curation, Y.G. and N.M.; writing-draft, Y.G. and P.J.; writing-reviewing and editing, Y.G, P.J., C.S.A., J.F.M. and N.M.; visualization, P.J. and Y.G.; supervision, P.J. and C.S.A.; project administration, P.J. and C.S.A.; funding acquisition, P.J. and C.S.A.

Funding: This research was funded by CONACYT and the British Council as part of the Newton Fund-Institutional links programme grant number 264771096.

Acknowledgments: We would like to thank ENMEX, Mexico for their kind donation of enzymes.

Conflicts of Interest: The authors declare no conflict of interest. The funders had no role in the design of the study; in the collection, analyses, or interpretation of data; in the writing of the manuscript, or in the decision to publish the results.

\section{References}

1. Armbruster, J.W. Redescription of Pterygoplichthys punctatus and description of a new species of Pterygoplichthys (Siluriformes: Loricariidae). Neotrop. Ichthyol. 2006, 4, 401-410. [CrossRef]

2. Mohanty, B.P.; Ganguly, S.; Mahanty, A.; Mitra, T.; Mahaver, L.; Bhowmick, S.; Paul, S.K.; Das, B.K. Nutritional compositon of the invasive Pterygoplichthys Disjunctivus from East Kolkata wetland. India. J. Inland Fish. Soc. India 2017, 49, 48-54.

3. Zamora-Sillero, J.; Tavares Kütter, M.; Borges Tesser, M.; Monserrat, J.M.; Prentice, C. Effect of dietary common carp by-product protein hydrolysates on antioxidant status in different organs of zebrafish (Danio rerio). Aquacult. Nutr. 2019, 25, 110-118. [CrossRef]

4. Nilsang, S.; Lertsiri, S.; Suphantharika, M.; Assavanig, A. Optimization of enzymatic hydrolysis of fish soluble concentrate by commercial proteases. J. Food Eng. 2005, 70, 571-578. [CrossRef]

5. Borawska, J.; Darewicz, M.; Pliszka, M.; Vegarud, G.E. Antioxidant properties of salmon (Salmo salar L.) protein fraction hydrolysates revealed following their ex vivo digestion and in vitro hydrolysis. J. Sci. Food Agric. 2016, 96, 2764-2772. [CrossRef]

6. Ovissipour, M.; Kenari, A.A.; Motamedzadegan, A.; Nazari, R.M. Optimization of Enzymatic Hydrolysis of Visceral Waste Proteins of Yellowfin Tuna. Food Bioprocess Technol. 2012, 5, 696-705. [CrossRef]

7. Chalamaiah, M.; kumar, B.D.; Hemalatha, R.; Jyothirmayi, T. Fish protein hydrolysates: Proximate composition, amino acid composition, antioxidant activities and applications: A review. Food Chem. 2012, 135, 3020-3038. [CrossRef]

8. Shahidi, F.; Naczk, M.; Pegg, R.B.; Synowiecki, J. Chemical composition and nutritional value of processing discards of cod. Food Chem. 1991, 42, 145-151. [CrossRef]

9. Vieira, G.H.F.; Martin, A.M.; Saker-Sampaiao, S.; Omar, S.; Goncalves, R.C.F. Studies on the enzymatic hydrolysis of Brazilian lobster (Panulirus spp.) processing wastes. J. Food Sci. Agric. 1995, 69, 61-65. [CrossRef]

10. Adler-Nissen, J. Enzymic Hydrolysis of Food Protein; Elsevier Applied Science: Barking, Essex, UK, 1986.

11. Saidi, S.; Belleville, M.-P.; Deratani, A.; Amar, R.B. Optimization of peptide production by enzymatic hydrolysis of tuna dark muscle by-product using commercial proteases. Afr. J. Biotechnol. 2013, 12, 1533-1547.

12. Lompong, V.K.; Benjakul, S.; Yachai, M.; Visessanguan, W.; Shahidi, F.; Hayes, K.D. Amino Acid Composition and AntioxidativePeptides from Protein Hydrolysates of Yellow Stripe Trevally (Selaroides leptolepis). J. Food Sci. 2009, 74, C126-C133. [CrossRef]

13. Khantaphant, S.; Benjakul, S.; Kishimura, H. Antioxidative and ACE inhibitory activities of protein hydrolysates from the muscle of brownstripe red snapper prepared using pyloric caeca and commercial proteases. Process Biochem. 2011, 46, 318-327. [CrossRef]

14. Prior, R.; $\mathrm{Wu}, \mathrm{X}$.; Schaich, K. Standardized methods for the determination of antioxidant capacity and phenolics in foods and dietary supplements. J. Agric. Food Chem. 2005, 53, 4290-4302. [CrossRef]

15. Pisoschi, A.M.; Negulescu, G.P. Methods for Total Antioxidant Activity Determination: A Review. Biochem. Anal. Biochem. 2011, 1, 1-10. [CrossRef]

16. Ortuño, J.; Serrano, R.; Jordán, M.; Bañón, S. Relationship between antioxidant status and oxidative stability in lamb meat reinforced with dietary rosemary diterpenes. Food Chem. 2016, 190, 1056-1063. [CrossRef] 
17. Qian, Z.-J.; Jung, W.-K.; Kim, S.-K. Free radical scavenging activity of a novel antioxidative peptide purified from hydrolysate of bullfrog skin, Rana catesbeiana Shaw. Bioresour. Technol. 2008, 99, 1690-1698. [CrossRef]

18. Lassoued, I.; Mora, L.; Nasri, R.; Aydi, M.; Toldra, F.; Aristoy, M.-C.; Barkia, A.; Nasri, M. Characterization, antioxidative and ACE inhibitory properties of hydrolysates obtained from thornback ray (Raja clavata) muscle. J. Proteomics 2015, 128, 458-468. [CrossRef]

19. Sai-Ut, S.; Benjakul, S.; Sumpavapol, P.; Kishimura, H. Effect of Drying Methods on Odorous Compounds and Antioxidative Activity of Gelatin Hydrolysate Produced by Protease from B. amyloliquefaciens H11. Drying Technol. 2014, 32, 1552-1559. [CrossRef]

20. Noriega, D.; ElviraZuñiga, M.; Soto, C.; Maidin, N.M.; Michael, N.; Jauregi, P. Colloidal Gas Aphrons separation to obtain polyphenol rich fractions from artichoke agro-industrial discards. Food Bioprod. Process. 2018, 110, 50-59. [CrossRef]

21. Rockenbach, I.I.; Rodrigues, E.; Gonzaga, L.V.; Caliari, V.; Genovese, M.I.; Souza Schmidt Gonçalves, A.E.; Fett, R. Phenolic compounds content and antioxidant activity in pomace from selected red grapes (Vitis vinifera L. and Vitis labrusca L.) widely produced in Brazil. Food Chem. 2011, 127, 174-179. [CrossRef]

22. Theodore, A.E.; Raghavan, S.; Kristinsson, H.G. Antioxidative Activity of Protein Hydrolysates Prepared from Alkaline-Aided Channel Catfish Protein Isolates. J. Agric. Food Chem. 2008, 56, 7459-7466. [CrossRef]

23. Wolfe, K.L.; Kang, X.; He, X.; Dong, M.; Zhang, Q.; Liu, R.H. Cellular Antioxidant Activity of Common Fruits. J. Agric. Food Chem. 2008, 56, 8418-8426. [CrossRef]

24. Sarmadi, B.H.; Ismail, A. Antioxidative peptides from food proteins: A review. Peptides 2010, 31, $1949-1956$. [CrossRef]

25. Hsieh, Y.H.P.; Hsieh, Y.P. Kinetics of Fe(III) reduction by ascorbic acid in aqueous solutions. J. Agric. Food Chem. 2000, 48, 1569-1573. [CrossRef]

26. Nielsen, P.M.; Petersen, D.; Dambamann, C. Improved Method for Determining Food Protein Degree of Hydrolysis. J. Food Sci. Food Chem. Toxicol. 2001, 66, 642-646. [CrossRef]

27. Re, R.; Pellegrini, N.; Proteggente, A.; Pannala, A.; Yang, M.; Rice-Evans, C. Antioxidant activity applying an improved ABTS radical cation decolorization assay. Free Radical Biol. Med. 1999, 26, 1231-1237. [CrossRef]

28. Benzie, I.F.F.; Strain, J.J. The ferric reducing ability of plasma (FRAP) as a measure of "antioxidant power": The FRAP assay. Anal. Biochem. 1996, 239, 70-76. [CrossRef]

29. Tecan Group Ltd. ORAC Assay for the determination of antioxidant capacity in foods. In Application Note; Tecan Group Ltd.: Männedorf, Switzerlan, 2013.

30. Cao, G.; Alessio, H.M.; Cutler, R.G. Oxygen-radical absorbance capacity assay for antioxidants. Free Radical Biol. Med. 1993, 14, 303-311. [CrossRef]

31. Murray, B.A.; Walsh, D.J.; FitzGerald, R.J. Modification of the furanacryloyl-l-phenylalanylglycylglycine assay for determination of angiotensin-I-converting enzyme inhibitory activity. J. Biochem. Biophys. Methods 2004, 59, 127-137. [CrossRef]

32. Wu, S.; Feng, X.; Lan, X.; Xu, Y.; Liao, D. Purification and identification of Angiotensin-I Converting Enzyme (ACE) inhibitory peptide from lizard fish (Saurida elongata) hydrolysate. J. Funct. Foods 2015, 13, $295-299$. [CrossRef]

33. Qiu, C.; Sun, W.Z.; Cui, C.; Zhao, M. Effect of citric acid deamidation on in vitro digestibility and antioxidant properties of wheat gluten. Food Chem. 2013, 141, 2772-2778. [CrossRef]

34. Sullivan, A.C.; Pangloli, P.; Dia, V.P. Impact of ultrasonication on the physicochemical properties of sorghum kafirin and in vitro pepsin-pancreatin digestibility of sorghum gluten-like flour. Food Chem. 2018, 240, 1121-1130. [CrossRef]

Sample Availability: Samples of the fish are available from the authors. 